\title{
Correction to: Peroxidasin Enhances Basal Phenotype and Inhibits Branching Morphogenesis in Breast Epithelial Progenitor Cell Line D492
}

\author{
Anna Karen Sigurdardottir ${ }^{1}$ - Arna Steinunn Jonasdottir ${ }^{1}$ - Arni Asbjarnarson ${ }^{1}$ - Hildur Run Helgudottir ${ }^{1}$. \\ Thorarinn Gudjonsson ${ }^{1,2}$ (D) . Gunnhildur Asta Traustadottir ${ }^{1}$ (i)
}

Published online: 12 February 2022

(c) The Author(s) 2022

\section{Correction to: Journal of Mammary Gland Biology and Neoplasia https://doi.org/10.1007/s10911-021-09507-1}

Due to an error during typesetting, an incomplete Supplementary file was originally published with this article. Supplementary figures were missing and this has now been uploaded.

The original article has been corrected.

Open Access This article is licensed under a Creative Commons Attribution 4.0 International License, which permits use, sharing, adaptation, distribution and reproduction in any medium or format, as long as you give appropriate credit to the original author(s) and the source, provide a link to the Creative Commons licence, and indicate if changes were made. The images or other third party material in this article are included in the article's Creative Commons licence, unless indicated otherwise in a credit line to the material. If material is not included in the article's Creative Commons licence and your intended use is not permitted by statutory regulation or exceeds the permitted use, you will need to obtain permission directly from the copyright holder. To view a copy of this licence, visit http://creativecommons.org/licenses/by/4.0/.

Publisher's Note Springer Nature remains neutral with regard to jurisdictional claims in published maps and institutional affiliations.

The original article can be found online at https://doi.org/10.1007/ s10911-021-09507-1.

Gunnhildur Asta Traustadottir gutra@hi.is

1 Stem Cell Research Unit, Biomedical Center, Department of Anatomy, Faculty of Medicine, School of Health Sciences, University of Iceland, Reykjavik, Iceland

2 Department of Laboratory Haematology, Landspitali University Hospital, Reykjavik, Iceland 